\title{
Arkistot ja kirjallisuudentutkimus - metodisia avauksia
}

SKS:n kirjallisuusarkisto ja EDITH (Suomalaisen kirjallisuuden kriittiset editiot) sekä Kirjallisuudentutkijain Seura järjestivät seminaarin "Arkistot ja kirjallisuudentutkimus - metodisia avauksia” 27.-28.3.2008 Tieteiden talossa Helsingissä. Seminaarin impulssina oli viime vuosina vahvistunut monipuolinen kiinnostus arkistoaineistoihin osana kirjallisuudentutkimuksen kenttää. Seminaarikutsussa pyydettiin esitelmiä aiheista, jotka käsittelevät arkistoaineistojen antia kirjallisuuden ja kirjallisuusinstituution tutkimukselle ja teoreettista kysymystä siitä, mihin paradigmaan mahtuvat arkistoidut jäljet kirjallisesta työstä.

Seminaaria leimasi innostunut keskustelu, mitä Kirjallisuusarkiston johtaja Anna Kuismin peräänkuuluttikin avaussanoissaan. Vuorovaikutus toteutui myös tieteenalojen välillä: paitsi kirjallisuudentutkimuksen alalta seminaarissa kuultiin myös muiden tieteenalojen edustajien esitelmiä. Näkökulmat laajenivat kirjahistoriaan, historiaan, filologiaan, folkloristiikkaan, kulttuurihistoriaan, naistutkimukseen, uskontotieteeseen ja estetiikkaan. Seminaarissa oli kaiken kaikkiaan 75 osallistujaa.

Kaksipäiväisessä kokoontumisessa kuultiin 19 esitelmää. Niissä tarkasteltiin sekä laajoja arkistokokonaisuuksia että yksittäisiä käsikirjoituksiakin. Käsittelyssä oli eri kirjoittamisen lajeja ja muotoja kirjeistä ja päiväkirjoista teosten työkäsikirjoituksiin ja käsin kirjoitettuun virsikokoelmaan. Suurin osa esitellystä aineistosta ajoittui 1900-luvun ensimmäiselle puoliskolle, mutta myös joitain 1800-luvun ja sitäkin varhaisempia tekstejä oli esillä.

Esitelmöitsijöiden suhde arkistoaineistoihin oli moni-ilmeinen. Toiset olivat paitsi hyödyntäneet arkistoja tutkimuksessaan, myös osallistuneet aineistojen kartuttamiseen, järjestämiseen, editoimiseen ja julkaisemiseen. Varsin paljon kuultiin käytännön kokemuksista aineistojen parissa. Moni oli kiinnostunut myös arkistotutkimuksen eettisistä kysymyksistä. Esitelmissä ja kommenttipuheenvuoroissa pohdittiin mitä aineistoja on luvallista kerätä, arkistoida ja tutkia. Aineistojen syntykontekstin tuntemisen tärkeyttä painotettiin toistuvasti. Myös monenlaiset tekstikriittiset kysymykset nousivat esille.

Seminaarin plenaristeina torstaina 27.3.2008 puhuivat tekstikritiikin asiantuntija ja Joyce-tutkija emeritusprofessori Hans Walter Gabler Münchenin yliopistosta sekä yleisen historian ja kirkkohistorian dosentti Tuomas Heikkilä Helsingin yliopistosta. Gabler puhui siitä, miten uusi tietotekniikka mahdollistaa sekä tekstikriitikoille että kirjallisuudentutkijoille arkistoaineistojen tutkimisen uudella tavalla. Elektronisessa ympäristössä saavutetaan toisentyyppinen lähestymistapa käsikirjoituksen dynaamiseen olemukseen kuin esimerkiksi pelkän valokopioidun käsikirjoituksen avulla. Ai- 
heensa havainnollistamiseksi Gabler esitteli viimeisimpiä luonnosaineistojen editointiin liittyviä innovaatioitaan. Gabler otti esitelmässään esille myös uuden geneettisen kritiikin, eli moderneihin käsikirjoituksiin keskittyvän tutkimussuunnan, näkemykset siitä, miten ensisijaista käsikirjoitusten ominaislaadun ymmärtämiselle on kiinnittää huomio aineistojen kehittyvään, "virtaavaan" kirjoitukseen.

Tieteellisen laitoksen Pyhän Henrikin legendasta toimittanut keskiajan erikoisasiantuntija Tuomas Heikkilä perehdytti kuulijat stemmatologiaan eli vanhojen tekstien variaatiohistorian tutkimukseen. Hän peräänkuulutti kirjallisuuden ja keskiaikaisten käsikirjoitusten tutkimuksen metodien vuorovaikutusta. Modernin tietotekniikan merkitys käsikirjoitustutkimukselle korostui myös hänen esitelmässään. Monet käsin kirjoitetut tekstit ovat sälyneet jälkipolville erilaisina versioina ja uusien tietoteknisten sovellusten myötä näiden tekstien variaation tutkimiselle on avautunut merkittäviä uusia mahdollisuuksia.

Torstaina pidettiin kaksi sektiota. Arkistot tutkimuksen lähteinä -sektion esitelmissä painottui arkistotutkimuksen konkreettinen puoli sekä aineistojen jäljittäminen eri arkistoista. Kiinnostavasti tuli myös esille, kuinka arkistoaineistoista löytynyt uusi tieto voi täydentää merkittävästikin painettuja lähteitä. Arkistot ja tekstikritiikki -sektion aihetta lähestyttiin moni-ilmeisesti. Esitelmät käsittelivät Japanin klassisen kirjallisuuden käsikirjoitusten erityispiirteitä, Arvid Järnefeltin päiväkirjamerkintöjä sekä Aleksis Kiven Kootut teokset toimittaneen E. A. Saarimaan arkistoa 2000-luvun kriittisten Kivieditioiden lähdemateriaaleina.

Päivän päätteeksi oli mahdollista tutustua Kirjallisuusarkistoon, sen henkilökuntaan ja aineistoihin sekä seminaarin muihin osallistujiin. Osa seminaariesitelmissä käsitellyistä aineistoista oli esillä Kirjallisuusarkiston tutkijasalissa. Moni seminaarilaisista osallistuikin Kirjallisuusarkiston tilaisuuteen, jossa keskustelut päivän aiheista jatkuivat vilkkaina.

Perjantain ohjelma koostui neljästä sektiosta. Arkistoaineistot ja tekijyys -sektiossa kirjan tekijää käsiteltiin ensin kirjahistoriallisesta näkökulmasta. Toisessa esitelmässä puhuttiin teoksen tekstuaalisesta variaatiosta ja sen kietoutumisesta tekijyyskysymykseen. Elämäkerta-aiheisissa esitelmissä kuultiin taidehistorioitsijan näkökulmasta kirjalliseen arkistoaineistoon, haastatteluaineiston suhteesta kirjailijakuvan rakentamiseen sekä 1910- ja 1920-lukujen työläiskirjailijoista. Kirjeitä ja muistelmia käsittelevässä sektiossa painopiste oli 1900-luvun alun kirjoittavissa naisissa: Ain’Elisabet Pennasessa, Aino Kallaksessa ja Anna-Maria Tallgrenissa. Päivän viimeisessä sektiossa tarkasteltiin intertekstuaalisuutta 1830-luvulla kirjoittaneen Kaisa Juhantyttären virsistä, Otto Mannisen runoluonnoksesta sekä Impi Kauppilan kirjeistä ja runoteoksesta.

Seminaarin loppukeskustelu oli eloisa. Paljon pohdittiin kirjallisuudentutkimuksen kontakteja lähitieteisiin. Painamattomien aineistojen tutkimisen hyötyjä ja vai- 
keuksia kommentoitiin runsaasti. Esitettiin, että käsitys kirjallisuuden olemuksesta muuttuu tuntuvasti, kun tarkastelupintaa avataan myös julkaisemattoman tuotannon eli arkistoaineiston puoleen. Siihen liittyy myös omat haasteensa. Aineistot ovat toisinaan vaikeasti luettavia ja tekstit hankalasti tulkittavia. Lisäksi tutkija saattaa kohdata vaikeuksia myös käsitteellisellä tasolla: kirjallisuudentutkimuksen peruskäsitteet ovat usein räätälöity julkaistulle kirjallisuudelle, ne eivät aina sovellu arkistomateriaalin tutkimiseen. Todettiin, että arkistotutkimukseen sopivien käsitteiden ja metodien kehittyminen vie oman aikansa. Keskustelussa peräänkuulutettiin myös aineistojen käyttöä helpottavaa vuorovaikutusta arkistojen ja tutkijoiden välillä. Kirjoittamisen ja kirjallisen teoksen komposition tutkimuksen mahdollisuuksia sekä nykytilannetta sivuttiin. Myös aineistojen editoinnin merkitystä korostettiin. Keskustelussa käsiteltiin erilaisten tekstiversioiden, kuten käsikirjoitusversioiden tai julkaistujen varianttien, lukemiseen liittyviä kysymyksiä: on esitetty, että lukijat kyllä oppivat lukemaan teosten versioita, jos varianttilukutapa tarjotaan ja opetetaan.

Loppukeskustelussa pohdittiin myös kirjallisuudentutkimuksen nykytilannetta. Tutkimuksen identiteetti on alituisesti muuttuva ja kiinnostus lähentyä muita tieteenaloja ja niiden teorioita ja metodeja on jälleen pinnalla. Ehdotettiin, että perinteisen hermeneuttisen tehtävän ohella kirjallisuudentutkimuksella voisi ajatella olevan myös arkistollisia velvollisuuksia. Tällä tarkoitettiin entistä monipuolisempaa otetta kirjallisen kentän arvioimisen, määrittelemisen ja dokumentoimisen suhteen.

\section{Hanna Miettinen}

\section{Suvi Ratinen}

